DOI: https://doi.org/10.24127/ajpm.v9i3.2885

\title{
PEMAHAMAN MAHASISWA CALON GURU PADA ANALOGI PROSEDUR MENYELESAIKAN PERSAMAAN KUADRAT DENGAN MEMFAKTORKAN
}

\author{
Abdul Haris Rosyidi \\ Universitas Negeri Surabaya, Surabaya, Indonesia \\ E-mail: $\quad$ abdulharis@unesa.ac.id
}

Received 25 June 2020; Received in revised form 23 September 2020; Accepted 26 September 2020

\begin{abstract}
Abstrak
Penelitian ini bertujuan untuk mendeskripsikan pemahaman mahasiswa terhadap analogi prosedur dalam menyelesaikan persamaan kuadrat dengan memfaktorkan akan dideskripsikan berdasar konsep pemahaman Skemp, pemahaman instrumental dan pemahaman relasional. Penelitian ini dilakukan terhadap 82 mahasiswa Prodi Pendidikan Matematika Universitas Negeri Surabaya. Instrumen penelitian berupa soal tes pemahaman dan wawancara. Data dianalisis menggunakan indikator pemahaman terhadap prosedur yang telah dipelajari, pemahaman terhadap prosedur baru, dan pemahaman terkait hubungan antara kedua prosedur tersebut. Hasil penelitian menunjukkan meski semua mahasiswa mampu menggunakan prosedur yang telah dipelajari tetapi hanya $15(18,29 \%)$ mahasiswa yang memahami bahwa teorema yang mendasari prosedur tersebut. Ada $5(6,10 \%)$ mahasiswa yang memahami prosedur baru, dan mampu menunjukkan aturan dibalik prosedur tersebut, tetapi hanya satu mahasiswa yang menemukan bentuk umum persamaan kuadrat yang dapat diselesaikan menggunakan prosedur baru sekaligus mampu mengembangkan prosedur baru yang analog lengkap dengan penjelasannya.
\end{abstract}

Kata kunci: Analogi prosedur; pemahaman; persamaan kuadrat.

\begin{abstract}
This research was conducted on 82 prospective teachers of Mathematics Education Study Program, Universitas Negeri Surabaya. Students' understanding of the analogy of procedures in solving quadratic equations by factoring will be described through concept of Skemp understanding, instrumental understanding and relational understanding. Indicators of these understanding are understanding of procedures that have been learned, understanding of new procedures, and understanding related to the relationship between the two procedures. The results showed that although all students were able to use the procedures learned, only 15 students $(18.29 \%)$ realized that the procedure relied on the multiplication theorem of two numbers equal to zero. There were 5 students $(6.10 \%)$ who understood the new procedure, and were able to show the rules behind the procedure, but only one student was able to find the general form of quadratic equations that could be solved using a new procedure while being able to develop new analogous procedures complete with an explanation
\end{abstract}

Keywords: Procedural analogy; quadratic equations; understanding.

This is an open access article under the Creative Commons Attribution 4.0 International License

\section{PENDAHULUAN}

Setiap topik matematika harus dipahami dengan baik oleh siswa. Setiap siswa harus belajar matematika dengan pemahaman, dan secara aktif membangun pengetahuan baru dari pengalaman dan pengetahuan awal mereka (CCSSO, 2010). Pemahaman yang dimaksud adalah membangun makna dari berbagai jenis fungsi baik itu pesan tertulis, grafik atau aktivitas seperti menafsirkan, mencontohkan, mengklasifikasikan, meringkas, menyimpulkan, membandingkan, atau menjelaskan (Wilson, 2016).

Untuk mengantar siswa menuju pemahaman, guru ataupun mahasiswa calon guru harus memahami secara 
DOI: https://doi.org/10.24127/ajpm.v9i3.2885

mendalam pengetahuan matematika yang diajarkannya. Hal paling pokok untuk mewujudkan tujuan tersebut adalah pemahaman seorang guru mengenai apa yang telah diketahui dan dibutuhkan siswa untuk belajar (Sidney \& Alibali, 2015), kemudian memberikan tantangan dan dukungan pada mereka agar mampu memahaminya dengan baik (CCSSO, 2000).

Salah satu tanda seseorang memahami sesuatu adalah mampu menemukan atau membuat hubungan antara apa yang baru saja dipelari dengan apa yang sudah dipelajari sebelumnya. Van de Walle (2013) menyatakan bahwa pemahaman merupakan ukuran kualitas dan kuantitas hubungan ide-ide baru dengan ide yang telah ada. Ukuran kualitas merujuk pada kejelasan hubungan antara ide baru dengan yang sudah ada, sedang ukuran kuantitas menunjukkan berapa banyak koneksi yang dapat dibangun antara ide baru dengan yang sudah ada.

Terkait dengan pemahaman seseorang terhadap suatu prosedur, Skemp (1976) membedakan dua jenis pemahaman, instrumental dan relasional. Pemahaman instrumental berarti mengetahui aturan dan prosedur tanpa memahami mengapa aturan atau prosedur tersebut bekerja, sedang pemahaman relasional bermakna mengetahui aturan atau prosedur sekaligus memahami mengapa aturan itu bekerja. Secara ringkas, Skemp menyatakan bahwa pemahaman instrumental dideskripsikan sebagai, "rules without reason" (p.2), sedang pemahaman relasional merupakan, "knowing both what to do and why" (p.2). Dengan pengertian tersebut, seorang guru atau calon guru tidak cukup hanya memiliki pemahaman instrumental terhadap suatu prosedur matematis yang akan dibelajarkan pada siswa.

Ada banyak penelitian yang menggunakan konsep pemahaman yang dikemukakan Skemp tersebut. Penelitian tentang pemahaman instrumental dan relasional tersebar pada berbagai topik dan subjek, konsep turunan menggunakan model matematis pada siswa (Sahin, Yenmez, \& Erbas (2015), perbandingan trigonometri pada mahasiswa (Yigit, 2016), persepsi spasial sudut dalam limas pada calon guru (Patkin, \& Plaksin, 2019).

Penelitian lain terkait pemahaman khususnya topik persamaan kuadrat juga telah banyak dilakukan. López, Robles, \& Martínez-Planell (2016) mengaji pemahaman mahasiswa pada persamaan kuadrat satu variable menggunakan teori APOS (ActionProcess-Object-Schema Theory), Fachrudin, \& Putri (2014) membangun pemahaman siswa materi persamaan kuadrat melalui geometri nä̈ve.

Dari beberapa penelitian tentang pemahaman khususnya pada topik menyelesaikan persamaan kuadrat, belum ada yang mencoba melihat keterkaitannya dengan analogi. Dalam hal ini, berkaitan dengan pemahaman prosedur "baru" dalam menyelesaikan persamaan kuadrat dengan memfaktorkan yang analog dengan prosedur sebelumnya.

Pemahaman terhadap analogi prosedur penting untuk diungkap karena hampir semua ide matematika bergantung pada analogi (Vendetti, at all, 2015). Hal ini mengisyaratkan bahwa analogi berperan dalam memahami hubungan antar prosedur juga konsep yang terlibat di dalamnya. Analogi juga berperan penting dalam pengembangan suatu prosedur (Vamvakoussi, 2017). 
DOI: https://doi.org/10.24127/ajpm.v9i3.2885

Analogi mengacu pada kemampuan untuk melihat dan menemukan kesamaan struktur (Lee \& Sriraman, 2011), dan berkenaan dengan kemampuan mentransfer representasi lintas konteks (White \& Mitchelmore, 2010). Dengan demikian analogi berperan penting dalam menyumbang pemahaman seseorang terhadap prosedur baru yang mempunyai struktur yang mirip dengan prosedur yang ia kenali.

Tujuan penelitian ini adalah mendeskripsikan pemahaman mahasiswa calon guru pada analogi prosedur menyelesaikan persamaan kuadrat dengan memfaktorkan.

\section{METODE PENELITIAN}

Penelitian ini merupakan penelitian deskriptif dengan tujuan mendiskripsikan pemahaman mahasiswa calon guru pada analogi prosedur menyelesaikan persamaan kuadrat dengan memfaktorkan. Subjek penelitian adalah 82 mahasiswa calon guru matematika Universitas Negeri Surabaya dengan rincian 34 orang mahasiswa tahun pertama, 24 orang mahasiswa tahun ke dua, dan 24 orang mahasiswa tahun ke tiga.

Pemahaman terhadap analogi prosedur dideskripsikan menggunakan 3 indikator, yaitu pemahaman terhadap prosedur yang telah dipelajari, pemahaman terhadap prosedur baru, dan pengetahuan tentang hubungan antara prosedur barudengan prosedur yang telah dipelajari. Analogi prosedur yang dideskripsikan menggunakan 3 indikator tersebut secara rinci dapat dilihat pada Tabel 1.

Instrumen penelitian yang digunakan dalam penelitian ini berupa tes tertulis (tes pemahaman analogi prosedur) dan wawancara. Tes tertulis terdiri dari dua soal. Tes tertulis berisi 2 soal tentang pemahaman analogi prosedur. Berikut soal tes tertulis tersebut.

1. Pada peubah bilangan real, tentukan penyelesaian dari persamaan $-x^{2}-x+12=6 . \quad$ Kemudian, tambahkan penjelasan setiap langkahnya untuk memastikan bahwa penyelesaian yang anda buat benar.

2. Perhatikan penyelesaian seorang siswa dari persamaan di atas berikut.

$$
\begin{gathered}
-x^{2}-x+12=6 \\
(x+4)(3-x)=6 \\
x+4=6 \text { atau } 3-x=6 \\
x=2 \text { atau } x=-3
\end{gathered}
$$

a. Apakah proses penyelesaian yang dilakukan siswa di atas benar dan logis, jelaskan!

b. Apakah ada persamaan kuadrat lain yang dapat diselesaikan menggunakan prosedur siswa tersebut. Jika ada, tuliskan salah satunya, dan selesaikan menggunakan prosedur tersebut. Jika tidak ada, mengapa?

c. Kapan prosedur di atas menghasilkan jawaban benar, jelaskan!

Soal tersebut dibuat dalam dua lembar, yang masing-masing lembar berisi 1 soal. Soal pertama pada lembar pertama dan soal kedua pada lembar kedua. Selanjutnya, subjek diminta untuk menyelesaikan soal pertama terlebih dahulu, dan setelahnya baru dibagikan soal kedua.

Wawancara yang akan dilakukan dalam penelitian adalah wawancara semi semi terstruktur. Wawancara didasarkan pada informasi yang dibutuhkan untuk mencapai hasil yang maksimal. Wawancara digunakan untuk melengkapi deskripsi tentang pemahaman dari subjek penelitian sehingga analisis menjadi lebih mendalam. 
DOI: https://doi.org/10.24127/ajpm.v9i3.2885

Tabel 1. Indikator dan Deskripsi Pemahaman Analogi Prosedur

\begin{tabular}{|c|c|c|}
\hline No. & Indikator & Deskripsi \\
\hline 1 & $\begin{array}{l}\text { Pemahaman terhadap } \\
\text { prosedur yang telah } \\
\text { dipelajari }\end{array}$ & $\begin{array}{l}\text { - Mampu menyelesaikan persamaan kuadrat } \\
\text { dengan memfaktorkan dengan benar dan runtut. } \\
\text { - Mampu menjelaskan setiap langkah dalam } \\
\text { menyelesaikan persamaan kuadrat dengan } \\
\text { memfaktorkan. } \\
\text { - Mampu menunjukkan konsep yang terlibat } \\
\text { dalam menyelesaikan persamaan kuadrat. }\end{array}$ \\
\hline 2 & $\begin{array}{l}\text { Pemahaman terhadap } \\
\text { prosedur baru }\end{array}$ & $\begin{array}{l}\text { - Mampu mengidentifikasi } \\
\text { penyelesaian persamaan kuadrat dengan } \\
\text { memfaktorkan yang berbeda dengan prosedur } \\
\text { yang dimiliki } \\
\text { - Mampu menjelaskan setiap langkah dalam } \\
\text { menyelesaikan persamaan kuadrat dengan } \\
\text { memfaktorkan yang berbeda dengan prosedur } \\
\text { yang dimiliki. } \\
\text { - Mampu menunjukkan konsep yang terlibat } \\
\text { dalam menyelesaikan persamaan kuadrat } \\
\text { dengan faktor yang berbeda dengan prosedur } \\
\text { yang dimiliki } \\
\text { - Mampu membuat contoh persamaan kuadrat } \\
\text { lain yang dapat diselesaikan dengan prosedur } \\
\text { baru } \\
\text { - Mampu membuat generalisasi penggunaan } \\
\text { prosedur baru menyelesaikan persamaan } \\
\text { kuadrat dengan mefaktorkan. }\end{array}$ \\
\hline 3 & $\begin{array}{l}\text { Pengetahuan tentang } \\
\text { hubungan antara prosedur } \\
\text { baru dengan prosedur yang } \\
\text { telah dipelajari }\end{array}$ & $\begin{array}{l}\text { - Mampu mengidentifikasi kesamaan atau } \\
\text { perbedaan dua prosedur menyelesaikan } \\
\text { persamaan kuadrat dengan memfaktorkan. } \\
\text { - Mampu membuat prosedur baru yang berbeda }\end{array}$ \\
\hline
\end{tabular}

\section{HASIL DAN PEMBAHASAN}

Semua subjek (82 orang atau $100 \%)$ dapat menyelesaikan persamaan kuadrat $-x^{2}-x+12=6$ dengan benar dan runtut dengan cara memfaktorkan, kecuali satu orang yang menggunakan rumus. Mereka juga mampu menjelaskan urutan langkah yang mereka gunakan. Secara umum langkah yang mereka gunakan untuk menyelesaikannya adalah mengenolkan (membuat menjadi $=0$ ) untuk salah satu ruas, memfaktorkan (ada juga yang mengalikan -1 terlebih dahulu sebelum memfaktorkan), dan mencari pembuat nol masing-masing faktor. Meski demikian hanya ada 15 subjek $(18,29 \%)$ yang menyadari bahwa langkah yang digunakan pada prosedur tersebut bersandar pada teorema jika $a \cdot b=0$ maka $a=0$ atau $b=0$. Lima belas subjek tersebut terdistribusi, 4 mahasiswa tahun ke tiga, 9 mahasiswa tahun ke dua, dan 2 mahasiswa tahun pertama. 
DOI: https://doi.org/10.24127/ajpm.v9i3.2885

Pemahaman subjek pada prosedur yang diberikan pada soal nomor dua dapat dideskripsikan sebagai berikut.

Dua puluh tujuh subjek $(32,93 \%)$, 20 orang mahasiswa tahun pertama, dan 7 mahasiswa tahun ke dua, menyatakan bahwa prosedur yang digunakan siswa tersebut benar dan logis. Ada 3 jenis alasan yang mereka gunakan untuk mendukung jawaban tersebut yaitu, (1) jawabannya runtut, dan bila disubstitusikan ke persamaan awal hasilnya benar, meski hal itu tidak berlaku untuk setiap persamaan kuadrat, (2) benar karena bila dicek dengan cara mengenolkan salah satu ruas hasilnya sama, dan (3) karena untuk menentukan nilai $x$ pada ruas kiri, ruas kanan tidak harus nol, membuat nol hanya bertujuan untuk mempermudah pemfaktoran atau mencari jawaban.

Dua puluh tiga $(28,05 \%)$ subjek, 11 mahasiswa tahun pertama, 2 mahasiswa tahun ke dua, dan 9 mahasiswa tahun ke tiga, menyatakan bahwa prosedur yang dilakukan siswa tersebut salah atau tidak logis. Mereka semua sepakat bahwa untuk menyelesaikan persamaan kuadrat tersebut harus dimulai dengan mengenolkan salah satu ruas, meski 11 orang dari mereka menyadari bahwa jawaban yang dihasilkan benar. Ada satu subjek dari kelompok ini yang menyatakan bahwa "persamaan $(x-a)(x-b)=c$ dapat kita tarik $x-a=c$ atau $x-b=c$ jika dan hanya jika $c=0$ ". Bahkan ada 5 subjek yang menambahkan argumen bahwa $(x+4)=6$ dan $(3-x)=6$ berarti $6 \cdot 6$ tidak sama dengan 6 , tetapi 36 .

Hanya ada 5 subjek $(6,10 \%), 1$ mahasiswa tahun pertama, dan 4 dari mahasiswa tahun ke dua, yang menyatakan bahwa prosedur tersebut tidak logis pada langkah ke-3, yaitu $x+4=6$ atau $3-x=6$. Mereka mampu menambahkan syarat agar prosedur tersebut benar, yaitu $x+4=$ 6 dengan syarat $3-x=1$, atau $3-x=6$ dengan syarat $x+4=1$. Mereka menyadari konsep dibalik prosedur tersebut adalah perkalian $a \cdot b=c$, dan mampu menerapkannya pada kedua kasus prosedur tersebut. Saat menyelesaikan soal nomor 1, mereka menyadari bahwa pada kasus tersebut $c=0$, dan sekaligus ada teorema yang mendasarinya. Sedang saat memahami prosedur pada soal nomor 2, mereka menyadari $c=6$, sehingga ketika $a=6$, maka $b$ harus sama dengan 1. Kelompok ini mampu menemukan hubungan antara prosedur yang mereka gunakan dengan prosedur baru yang analog.

Dua puluh tujuh $(32,93 \%)$ subjek, 1 mahasiswa tahun ke tiga, 2 mahasiswa tahun ke dua, dan 24 mahasiswa tahun pertama, juga menyatakan bahwa prosedur tersebut tidak logis pada langkah ke tiga dengan alasan tidak ada teorema yang mendasarinya atau menjaminnya. Mereka juga berpendapat bahwa benarnya prosedur itu karena kebetulan. Prosedur yang benar tetap harus mengenolkan salah satu ruas terlebih dahulu.

Tujuh puluh $(85,37 \%)$ subjek, 22 mahasiswa tahun ke tiga, 20 mahasiswa tahun ke dua, dan 28 mahasiswa tahun pertama, tidak mampu menemukan contoh persamaan kuadrat lain yang dapat diselesaikan menggunakan prosedur siswa tersebut. Mereka berargumen bahwa karena cara tersebut kebetulan benar atau cara tersebut tidak selalu menghasilkan jawaban benar.

Dua belas $(14,63 \%)$ subjek, 2 mahasiswa tahun ke tiga, 6 mahasiswa tahun ke dua, dan 4 mahasiswa tahun pertama, dapat membuat contoh lain dan mampu menyelesaikannya dengan cara tersebut. Kelima belas contoh yang 
DOI: https://doi.org/10.24127/ajpm.v9i3.2885

dibuat berpola sama dengan persamaan kuadrat yang ada pada soal, yaitu koefisien $x^{2}$ dan $x$ merupakan bilangan negatif. Mereka menyusun persamaan kuadrat tersebut dengan terlebih dahulu membuat bentuk

$$
(x+\ldots)(\ldots-x)=\cdots,
$$

kemudian dengan cara coba-coba mencari bilangan yang tepat untuk mengisi ketiga titik-titik tersebut. Ada 5 variasi contoh persamaan kuadrat yang dibuat subjek, yaitu:

$$
-x^{2}-x+20=8, \quad-x^{2}-2 x+15=7,
$$$$
-x^{2}-x+42=12,-x^{2}-x+6=4
$$

(subjek banyak yang menggunakan contoh kedua), dan

$-x^{2}-2 x+8=5$.

Berikut contoh penyelesaian mereka

$-x^{2}-x+6=4$

$(-x+2)(x+3)=4$

$-x+2=4$ atau $x+3=4$

$x=-2$ atau $x=1$

Hanya ada 2 (2,44\%) subjek, 1 mahasiswa tahun ke tiga, dan 1 mahasiswa tahun ke dua, yang mampu menjustifikasi kapan prosedur tersebut menghasilkan jawaban benar. Mereka menyatakan bahwa prosedur tersebut akan menghasilkan jawaban benar bila persamaan kuadratnya berbentuk $(x+a)(b-x)=c$ dengan syarat $a+b-c=1$. Sebenarnya ada 4 subjek lain yang mencoba membuat generalisasi itu, tetapi tidak lengkap. Salah satu contohnya adalah persamaan kuadrat $(x-a)(x-b)=c \quad$ dapat diselesaikan dengan prosedur di atas bila memenuhi $(x-a)=c \quad$ dan $(x-b)=1$ atau $(x-a)=1$ dan $(x-b)=c$. Namun, ketika subjek tersebut ditanya lebih lanjut, mereka tidak dapat menjelaskannya.

Dua subjek yang mampu menemukan bentuk umum persamaan kuadrat tersebut, namun hanya satu yang dapat menjelaskannya dengan cermat. Berikut hasil wawancara dengan satu subjek tersebut.

( $\mathrm{P}=$ Peneliti, $\mathrm{S}=$ subjek $)$

P: Dari mana kamu mendapatkan hubungan $a+b-c=1$ ?

$\mathrm{S}$ : Pertama saya melihat jawaban anak tersebut dan menganalisisnya. (sambil menunjuk soal nomor 2)

P: Bagaimana cara menganalisnya?

S: Sambil saya tuliskan (Gambar 1) ya Pak. Dari langkah ke dua $(x+$ 4) $(3-x)=6$ saya mendapatkan $x+4=6$ dan $3-x=1$ atau $x+4=1$ dan $3-x=6$, kemudian saya menyamakan $a=4, b=3$ dan $c=6$. Dari sepasang persamaan pertama maupun sepasang persamaan ke dua, dengan menyubstitusi $x$, saya memperoleh hubungan $a+b-c=1$.

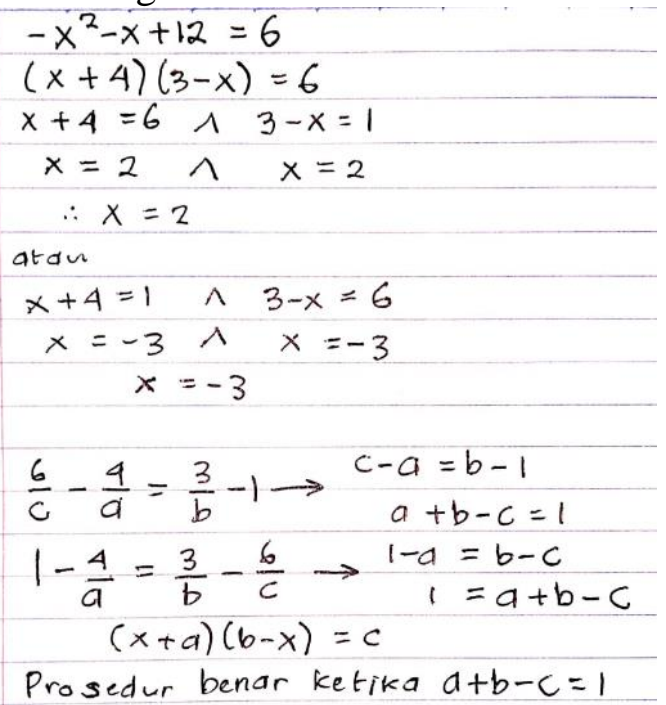

Gambar 1. Penyelesaian subjek terkait hubungan $a, b$ dan $c$

P: Dapatkah kamu langsung menganalis dari persamaan $(x+a)(b-x)=c$ ?

S: Bisa pak, begini.

$$
\begin{aligned}
& (x+a)(b-x)=c \\
& x+a=c \text { dan } b-x=1 \text { atau } \\
& x+a=1 \text { dan } b-x=c \\
& \text { Dari } x+a=c \text {, diperoleh } x=c- \\
& a, \quad \text { sehingga bentuk } b-x=1 \\
& \text { menjadi } b-(c-a)=1, \quad \text { dapat }
\end{aligned}
$$


DOI: https://doi.org/10.24127/ajpm.v9i3.2885

disederhanakan menjadi $a+b-c=$ 1.Sama juga untuk sepasang persamaan kedua pak. Dari $x+a=$ 1, diperoleh $x=1-a$, sehingga bentuk $b-x=c$ menjadi $b-(1-$ a) $=c$, dapat disederhanakan menjadi $a+b-c=1$.

Karena hubungan $a, b$, dan $c$ dari sepasang persamaan pertama dan sepasang persamaan ke dua sama, maka saya simpulkan bentuk persamaan kuadrat $(x+a)(b-$ $x)=c \quad$ dapat diselesaikan menggunakan cara siswa tersebut bila $a+b-c=1$.

P: Dapatkah kamu memberikan contoh selain yang kamu buat sebelumnya? (catatan: subjek sebelumnya memberikan contoh $-x^{2}-2 x+$ $15=7$ untuk menjawab soal nomor 2b)

S: Saya pilih saja $a=2, b=3$, dan $c=4$, dan saya masukkan ke persamaan $\quad(x+a)(b-x)=c$, menjadi $(x+2)(3-x)=4$. Jadi persamaannya menjadi $-x^{2}+x+$ $6=4$.

P: Coba selesaikan dengan cara siswa yang ada dalam soal!

$\mathrm{S}$ : Begini pak.

$$
\begin{aligned}
& -x^{2}+x+6=4 \ldots \ldots \ldots \\
& (x+2)(3-x)=4 \ldots \ldots \ldots \\
& x+2=4 \text { atau } 3-x=4 \ldots \\
& x=2 \text { atau } x=-1 \ldots \ldots \ldots
\end{aligned}
$$

P: Apakah tidak ada persamaan kuadrat berbentuk $(x-a)(x-b)=c$ yang dapat diselesaikan dengan cara siswa tersebut?

S: Saya mencoba menuliskan jawabannya (Gambar 2) ya pak.

Dari bentuk $(x-a)(x-b)=c$ saya selesaikan mirip dengan sebelumnya. Tetapi, prosedur itu cuma nemu salah satu akarnya saja pak, dengan pola $a=b$ dan $c=1$.

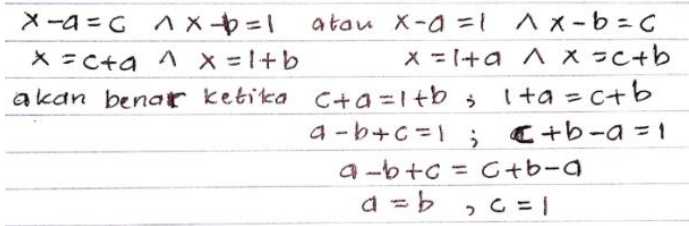

Gambar 2. Penyelesaian subjek terkait hubungan $a, b$ untuk $c=1$.

Tetapi, prosedur itu cuma nemu salah satu akarnya saja pak, dengan pola $a=b$ dan $c=1$.

P: Apakah kamu bisa membuat cara lain yang analog dengan cara siswa?

S: Sebenarnya banyak si pak. Salah satunya adalah seperti ini (Gambar 3) Dan itu sebenarnya bisa diperumum kalau $(x+a)(b-x)=c$ mau pake cara $\quad x+a=\frac{c}{n} \quad$ atau $\quad b-x=\frac{c}{n}$ syaratnya $a+b-\frac{c}{n}=n$ dengan $n$ bukan 0 .

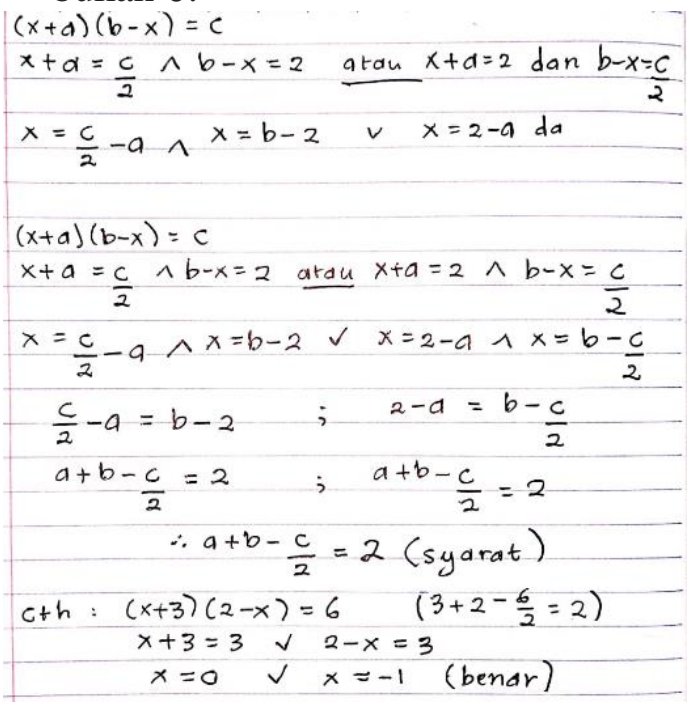

Gambar 3. Penyelesaian subjek terkait prosedur baru

Hasil ini mengindikasikan bahwa sebagian besar mahasiswa calon guru masih mempunyai pemahaman instrumental terhadap prosedur menyelesaikan persamaan kuadrat dengan memfaktorkan. Mereka mampu menyelesaikan persamaan kuadrat tanpa pemahaman mengapa prosedur tersebut 
DOI: https://doi.org/10.24127/ajpm.v9i3.2885

dapat dilakukan. Sebagian mereka menyadari teorema yang mendasari prosedur tersebut, tetapi tidak sepenuhnya paham. Sebagai bukti mereka tidak mampu mentransfer pemahamannya untuk menjustifikasi kebenaran prosedur "baru" yang sebenarnya analog dengan cara mereka memfaktorkan. Hal ini tidak berbeda dengan hasil penelitian Didis, Bas, dan Erbas (2011) dengan subjek siswa sekolah menengah.

Hasil dari penyelesaian soal pertama juga menguatkan pendapat Didis, Bas, dan Erbas (2011) bahwa memfaktorkan menjadi cara yang lebih disukai dalam menyelesaikan persamaan kuadrat. Hanya 1 subjek dari 82 orang mahasiswa yang menggunakan rumus kuadrat untuk menyelesaikannya, sedang lainnya menggunakan cara memfaktorkan. Meski berbeda subjeknya, hasil penelitian ini juga menguatkan pandangan bahwa cara memfaktorkan ini dipahami prosedurnya tetapi tidak dengan struktur dan konsepnya (Taylor and Mittag, 2001; Sönnerhed, 2009). Hasil penelitian ini menunjukkan bahwa hanya ada 15 subjek yang memberikan tambahan penjelasan bahwa prosedur pemfaktoran yang mereka gunakan bersandar pada satu teorema bahwa untuk setiap bilangan real $a, b$, jika $a b=0$ maka $a=0$ atau $b=0$.

Dari 15 subjek tersebut, hanya ada 5 subjek yang mampu mentransfer struktur teorema tersebut ke prosedur baru. Mereka menyadari bahwa prosedur penyelesaian siswa di soal nomor 2, tidak sepenuhnya sama dengan teorema jika $a b=0$ maka $a=0$ atau $b=0$. Mereka menemukan struktur persamaan $a b=c$ pada teorema tersebut yang pada akhirnya digunakan untuk melengkapi prosedur yang digunakan siswa. Mereka menyatakan bahwa prosedur yang digunakan siswa tersebut harus dilengkapi syarat $(x+3)=1$ untuk $(-x+2)=4, \quad$ juga $\quad(-x+2)=1$ untuk $\quad(x+3)=4$. Mereka menganalogikannya dengan persamaan $a b=c$, dengan $c=4$, dan $a=4, b=$ 1 , atau $a=1, b=4$.

Dari aspek kemampuan memberikan contoh yang merupakan salah satu indikator pemahaman (Anderson \& Krathwohl, 2010), hanya ada 12 subjek yang menemukan contoh persamaan kuadrat lain yang dapat diselesaikan menggunakan prosedur siswa. Persamaan kuadrat yang mereka temukan berbentuk $(x-a)(b-x)=$ $c$, yang analog dengan bentuk persamaan kuadrat yang diselesaikan siswa.

Dari pengertian pemahaman relasional yang dikemukakan Skemp, hanya 1 mahasiswa calon guru yang memiliki pemahaman jenis ini. Ia mampu mengaitkan prosedur sebelumnya dengan prosedur baru, kemudian menggunakan pemahamannya untuk membuat generalisasi bentuk persamaan kuadrat yang dapat diselesaikan menggunakan cara siswa. Hasil generalisasi subjek tersebut adalah persamaan kuadrat berbentuk $(x-a)(b-x)=c$ dengan syarat $a+b-c=1$. Ia juga mampu menjelaskan dengan baik dari mana generalisasi itu didapat, dan mengapa hasil tersebut benar. Subjek ini mempunyai pemahaman yang baik terhadap domain sumber (dalam hal ini pemahaman terhadap konsep dan prosedur menyelesaikan persamaan kuadrat dengan memfaktorkan), juga terhadap domain target. Hal ini sesuai dengan pendapat Huang \& Kapur, (2015) yang menyatakan bahwa keberhasilan analogi ditentukan oleh pemahaman terhadap domain sumber 
DOI: https://doi.org/10.24127/ajpm.v9i3.2885

dan domain target. Satu mahasiswa ini juga mampu mengembangkan prosedur baru yang analog lengkap dengan penjelasan yang meyakinkan.

\section{KESIMPULAN DAN SARAN}

Hasil penelitian menunjukkan bahwa sebagian besar mahasiswa calon guru masih mempunyai pemahaman instrumental terkait prosedur menyelesaikan persamaan kuadrat dengan memfaktorkan. Dengan bantuan analogi, pemahaman struktur prosedur penyelesaian persamaan kuadrat dengan memfaktorkan menuntun seseorang pada pemahaman pengembangan prosedur tersebut. Ada banyak prosedur matematis yang sejatinya merupakan pengembangan dari prosedur sebelumnya, misal dari prosedur menyelesaikan sistem persamaan linier dua variabel menuju prosedur menyelesaikan persamaan linier tiga variabel. Dengan berbantuan analogi, perlu dikaji apakah prosedur-prosedur hasil pengembangan tersebut dapat ditemukan atau dapat dipahami sendiri oleh siswa dengan "tanpa" campur tangan guru.

\section{DAFTAR PUSTAKA}

Anderson, L. W., \& Krathwohl, D. R. (2010). Kerangka landasan untuk pembelajaran, pengajaran, dan asesmen. Yogyakarta: Pustaka Pelajar, 300(300), 0.

Council of Chief State School Officers. (2010). Common core state standards for mathematics. Washington, DC: Council of Chief State School Officers.

Didiş, M. G., Baş, S., \& Erbaş, A. (2011). Students' reasoning in quadratic equations with one unknown. In The Seventh Congress of the European
Society for Research in Mathematics Education (CERME-7) (pp. 479-489).

Fachrudin, A. D., \& Putri, R. I. I. (2014). Building Students' Understanding of Quadratic Equation Concept Using Naïve Geometry. Indonesian

Mathematical Society Journal on Mathematics Education, 5(2), 192-202.

Huang, J. S., \& Kapur, M. (2015). Can "less" create "more" in analogical reasoning?. Learning: Research and Practice, 1(2), 133-151.

Lee, K. H., \& Sriraman, B. (2011). Conjecturing via reconceived classical analogy. Educational studies in mathematics, 76(2), 123-140.

López, J., Robles, I., \& MartínezPlanell, R. (2016). Students' understanding of quadratic equations. International Journal of Mathematical Education in Science and Technology, 47(4), 552-572.

Patkin, D., \& Plaksin, O. (2019). Procedural and relational understanding of pre-service mathematics teachers regarding spatial perception of angles in pyramids. International Journal of Mathematical Education in Science and Technology, 50(1), 121-140.

Sahin, Z., Yenmez, A. A., \& Erbas, A. K. (2015). Relational Understanding of the Derivative Concept through Mathematical Modeling: A Case Study. Eurasia Journal of 
DOI: https://doi.org/10.24127/ajpm.v9i3.2885

Mathematics, Science \& Technology Education, 11(1).

Sidney, P. G., \& Alibali, M. W. (2015). Making connections in math: activating a prior knowledge analogue matters for learning. Journal of Cognition and Development, 16(1), 160185.

Skemp, R. (1976). Instrumental understanding and relational understanding. Mathematics Teaching, 77, 20-26.

Sönnerhed, W. W. (2009). Alternative approaches of solving quadratic equations in mathematics teaching: An empirical study of mathematics textbooks and teaching material or Swedish Uppersecondary school. Retrieved April 5, 2010, from http://www.ipd.gu.se/digitalAsse ts/1272/1272539_plansem_wei.p df.

Taylor, S. E., \& Mittag, K. G. (2001). Seven wonders of the ancient and modern quadratic world. The Mathematics Teacher, 94(5), 349.

Van de Walle, John A. (2013) Elementary and middle school mathematics: teaching developmentally / John A. Van de Walle,Karen S. Karp; Jennifer M. Bay-Williams; with contributions by Jonathan Wray.-8th ed. New Jersey.
Vamvakoussi, X. (2017). Using analogies to facilitate conceptual change in mathematics learning. ZDM, 49(4), 497-507.

Vendetti, M. S., Matlen, B. J., Richland, L. E., \& Bunge, S. A. (2015). Analogical reasoning in the classroom: Insights from cognitive science. Mind, Brain, and Education, 9(2), 100-106.

White, P., \& Mitchelmore, M. (2010). Teaching for abstraction: A model. Mathematical Thinking and Learning, 12(3), 205-226.

Wilson, L. O. (2016). Anderson and Krathwohl-Bloom's taxonomy revised. Understanding the New Version of Bloom's Taxonomy.

Yiğit Koyunkaya, M. (2016). Mathematics education graduate students' understanding of trigonometric ratios. International Journal of Mathematical Education in Science and Technology, 47(7), 1028-1047. 